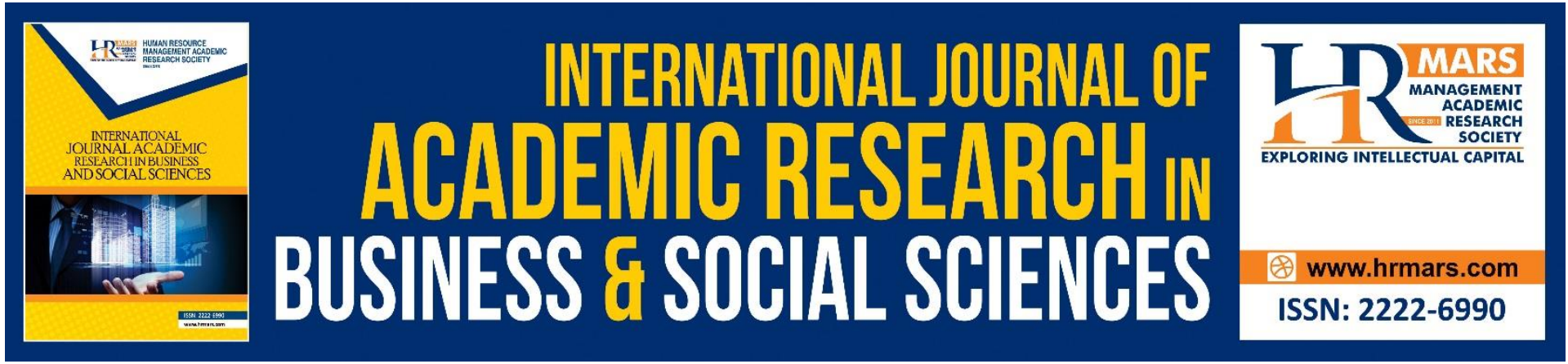

\title{
Discovering the Intangible Innovation of Knowledge Sharing for Improving Rural Tourism Destinations' Competitiveness: A Collaborative Approach
}

Chee-Hua Chin, Winnie Wong Poh Ming, Chee-Ling Chin \& Franklin George

To Link this Article: http://dx.doi.org/10.6007/IJARBSS/v11-i8/10655

DOI:10.6007/IJARBSS/v11-i8/10655

Received: 17 June 2021, Revised: 25 July 2021, Accepted: 18 August 2021

Published Online: 26 August 2021

In-Text Citation: (Chin et al., 2021)

To Cite this Article: Chin, C.-H., Ming, W. W. P., Chin, C.-L., \& George, F. (2021). Discovering the Intangible Innovation of Knowledge Sharing for Improving Rural Tourism Destinations' Competitiveness: A Collaborative Approach. International Journal of Academic Research in Business and Social Sciences, 11(8), 1728-1747.

Copyright: (c) 2021 The Author(s)

Published by Human Resource Management Academic Research Society (www.hrmars.com)

This article is published under the Creative Commons Attribution (CC BY 4.0) license. Anyone may reproduce, distribute, translate and create derivative works of this article (for both commercial and non-commercial purposes), subject to full attribution to the original publication and authors. The full terms of this license may be seen at: http://creativecommons.org/licences/by/4.0/legalcode

Vol. 11, No. 8, 2021, Pg. 1728 - 1747

Full Terms \& Conditions of access and use can be found at http://hrmars.com/index.php/pages/detail/publication-ethics 


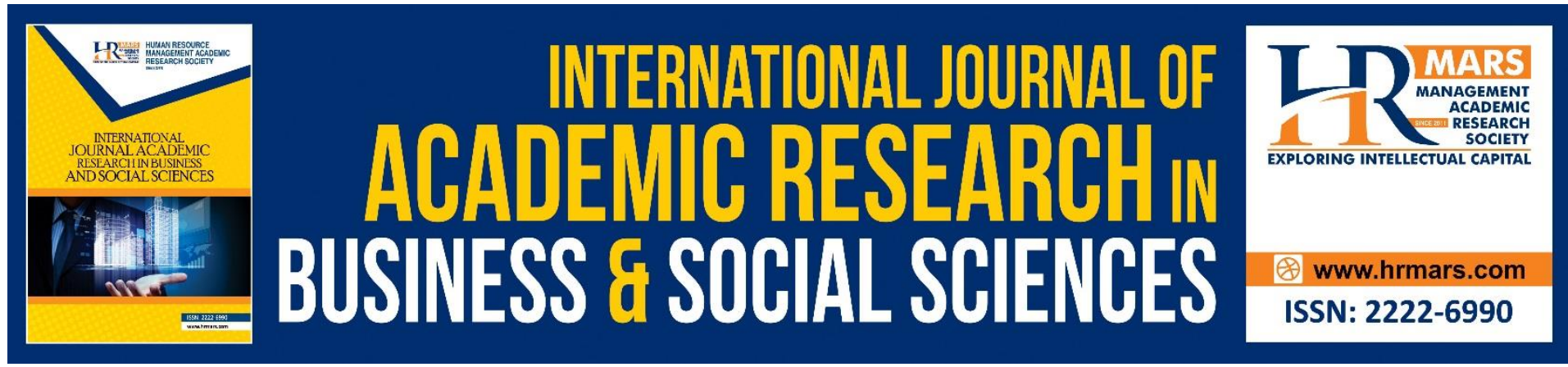

\title{
Discovering the Intangible Innovation of Knowledge Sharing for Improving Rural Tourism Destinations' Competitiveness: A Collaborative Approach
}

\author{
Chee-Hua Chin ${ }^{1}$, Winnie Wong Poh Ming ${ }^{2}$, Chee-Ling Chin ${ }^{3}$ \& \\ Franklin George ${ }^{4}$ \\ ${ }^{1,2}$ School of Business and Management, University College of Technology Sarawak, ${ }^{3}$ Faculty \\ of Economics and Business, Universiti Malaysia Sarawak, ${ }^{4}$ People's Association for \\ Development and Education of Penan Sarawak
}

Email: chincheehua@ucts.edu.my

\begin{abstract}
The study is possibly the first to examine the role of knowledge sharing in enhancing the competitiveness of rural tourism destinations, with a particular emphasis on sustainable management, destination marketing efforts, and comparative and competitive advantage. 315 valid questionnaires were collected from domestic and international visitors to Sarawak's five rural tourism destinations. A PLS-SEM approach was used to evaluate the developed model, with PLS estimation and hypothesis testing performed using the WarpPLS software. Interestingly, the statistical findings indicate that knowledge sharing has a significant effect on rural tourism destinations' competitiveness. The findings unavoidably contributed to the fundamental concept of destination competitiveness by identifying knowledge sharing as a resource for developing rural tourism destination competitiveness and its contribution to sustainable management, destination marketing efforts, as well as the comparative and competitive advantage of rural tourism destinations that are currently underdeveloped. This study contributes a comprehensive picture of how an intangible innovation can help develop a tourism destination's competitiveness. Future research should concentrate on identifying appropriate platforms to facilitate knowledge sharing among tourism stakeholders.
\end{abstract}

Keywords: Knowledge Sharing, Destination Competitiveness, Social Exchange Theory, Rural Tourism, PLS-SEM, Malaysia.

\section{Introduction}

The tourism industry is widely recognised as a source of lucrative income for local communities and a significant contributor to the country's economic growth (Scott et al., 2019). Numerous studies have been conducted in the past to demonstrate the economic benefits of rural tourism in enhancing community livelihoods (Joyner et al., 2018). Over the years, researchers have conducted a number of studies on rural tourism destinations in Malaysia (i.e., Cheuk et al., 2015; Jaafar et al., 2015). A recent example is Rajaratnam and 
Nair's (2015) study, which examined a few rural tourist destinations in Malaysia, specifically Bario, Gopeng, Pangkor, Taman Negara, and Royal Belum. This study identified eight primary attributes that contributed to the destination quality of rural tourism destinations (i.e., amenities, accessibility and logistics, core tourism experience, hygiene, information, security, value for money, and hospitality). Another example is a study conducted in Mersing, Malaysia, which discovered that tourism activities successfully contributed to the community's positive economic impact (Sapari et al., 2019). Thus, it has been noted in Malaysia that rural tourism is increasingly being viewed as a means of alternative income generation for rural communities (Joyner et al., 2018).

However, with the discovery of the novel Coronavirus Severe Acute Respiratory Syndrome 2 (SARS-CoV-2), the world has been plunged into turmoil by the Coronavirus Disease 2019 (COVID-19) pandemic. As a result, global business activity has come to a halt, which has had a significant impact on the tourism industry. Nonetheless, in the post-COVID-19 era, rural tourism and ecotourism destinations remain a top priority for the Malaysian Ministry of Tourism, Arts, and Culture in order to rebuild the country's tourism industry. Rural tourism is also expected to see an increase in visitors over the next year or two, as tourists seek less crowded vacation destinations. For example, one of Sarawak's initiatives is the "Sia Sitok Sarawak" intrastate tour packages. The initiative is a collaboration between the Sarawak Tourism Board (STB) and the Sarawak Tourism Federation (STF) to promote intrastate tourism in Sarawak, with an emphasis on ecotourism and rural tourism destinations. As a result, rural tourism remains relevant in the Malaysian context post-pandemic.

Previous researchers have emphasised the importance of identifying factors that contribute to the development of tourism destination competitiveness, as this could potentially benefit the tourism industry significantly (Demirovi et al., 2016). However, given today's enormous development and increasing challenges, particularly post-pandemic tourism development (Campón-Cerro et al., 2017), innovation has emerged as the primary factor that differentiates one rural tourism destination from another, particularly in determining a tourism destination's level of competency, and "knowledge" has long been recognised as the key to success (Albino et al., 2010). Previous research has repeatedly affirmed that innovation can be classified into tangible and intangible innovations (Fouad et al., 2017; Silva and Oliveira, 2020). Tangible innovation is related with physical products, whereas intangible innovation is associated with the knowledge, skills, and processes necessary to generate long-term value. UNDP (2013) emphasised the importance of acquiring new knowledge in order to improve living conditions in rural areas. Ali and Avdic (2015) investigated the use of a knowledge management framework for the development of sustainable rural tourism.

Subsequently, knowledge sharing is regarded as a critical component for the longterm development of tourism destination competitiveness, because knowledge sharing among individuals can result in the creation of new knowledge for tourism development (Odunga et al., 2020). At the rural tourism destination level, community members are eager to learn and continuously improve their services, particularly as they interact with tourists. Some tourists may travel frequently to various rural tourism destinations; as a result, they are the best people to consult and obtain constructive feedback and knowledge for improving the competitiveness of rural tourism destinations. As a result, this research is the first to apply the collaborative approach by examining the critical role of knowledge sharing in the 
development of rural tourism destination competitiveness, a topic that has received little attention in the literature. Second, this study contributes a comprehensive picture of how an intangible innovation can help develop a tourism destination's competitiveness. Finally, this study provides evidence that Social Exchange Theory was used as the guiding theory for the research framework on knowledge sharing among stakeholders. In short, the findings of this study benefit tourism stakeholders in Sarawak, particularly those who rely on tourism activities for a living (i.e., community members, homestay operators, and local tour guides), by enhancing the management and development of rural tourism destinations for competitiveness. If the study is successful in Sarawak, the model can be replicated in other rural tourism destinations throughout Malaysia and other countries.

\section{Literature Review}

\section{Social Exchange Theory and Rural Tourism Destination Competitiveness}

The Social Exchange Theory emphasises the relationship between an interaction or resource exchange between two parties (individuals or groups) [Ap, 1992], with the goal of assessing and comprehending the behaviour of the individuals involved in the interactions (Cropanzano and Mitchell, 2005). The exchange of resources between two parties is frequently governed by the cost-benefit principle (Wang and Pfister, 2008). Previous research has demonstrated that Social Exchange Theory can be used to explain why and how people react to and support tourism development (Lee, 2013). On the other hand, previous research has established that Social Exchange Theory is the fundamental theory for comprehending and explaining knowledge sharing behaviours (Molose and Ezeuduji, 2015). It is critical to recognise that knowledge sharing among tourism stakeholders is a form of social interaction and knowledge exchange (Bock et al., 2005). According to Kim and Lee (2013), knowledge sharing is the process by which individuals exchange knowledge in order to jointly create new knowledge.

In rural tourism, the benefits of social exchange are not primarily economic or monetary; rather, they are relationship building (Cook, 2000), as tourists share their knowledge or experience dealing with other rural tourism destinations with community members from the current one. Knowledge sharing is regarded as a critical component of developing one's competitive capabilities in the current competitive environment (Nickerson and Zenger, 2004). Due to the increasingly competitive environment, numerous previous studies have used the Resource Based View as the fundamental theory to underpin the research framework on innovation and knowledge as resources for organisational competency enhancement (Hansen and Schaltegger, 2016; Guenther and Heinicke, 2019; Silva and Oliveira, 2020). According to those studies, knowledge is considered an intangible resource that aids in the innovation process. However, the current study sought to demonstrate that tourists' perspectives and willingness to support the knowledge sharing process would be an added benefit to rural tourism destinations' competitiveness development. As a result, it was determined that Social Exchange Theory was more appropriate for establishing the study's research framework. Thus, this paper applied Social Exchange Theory to examine the potential for knowledge sharing to contribute to the development of rural tourism destination competitiveness through sustainable management, destination marketing efforts, and comparative and competitive advantage. 


\section{Rural Tourism Destination Competitiveness}

There is an increased emphasis and focus in the tourism literature on research on the concept of destination competitiveness from a different perspective (Rahmiati et al., 2020). Numerous studies have established that it is pivotal for a tourism destination to identify the unique selling propositions that contribute to the sustainable development of the destination's competitiveness (Ching et al., 2019; Rodrguez-Daz and Pulido-Fernández, 2020) in light of the current tourism marketplace's increasing competition (Guo et al., 2020). Several definitions of the terms "competitiveness," "destination competitiveness," and "tourism destination competitiveness" have been developed over the last decade. The term "competitiveness" was coined in the context of an organisation (Porter, 1990) and serves as a critical component of management and marketing strategy (Fornell, 1992). A business is said to be competitive if it can achieve a favourable competitive position in its industry through the use of an effective competitive strategy (Porter, 1985). According to Newall (1992), competitiveness is defined as "producing more and higher-quality goods and services that are successfully marketed to consumers." In a similar vein, previous researchers have proposed that the term "competitiveness" refers to the combination of assets and processes, where competitiveness is achieved through the processing and transformation of both natural and created resources into economic results (Crouch and Ritchie, 1999).

Porter's dynamic diamond model (Porter, 1990) was one of the earliest models of destination competitiveness. It incorporates four key elements (such as factor conditions, demand conditions, related and supporting industries, and firm strategy, structure, and rivalry) to develop tourism destination competitiveness. Crouch and Ritchie (1999) proposed a subsequent destination competitiveness model that incorporates a variety of competitive factors classified into three broad categories: (i) nation-specific, (ii) industry-specific, and (iii) firm-specific. Essentially, this model considers both tourism-specific (i.e., core resources and attractor factors) and business-related factors when determining a tourism destination's competitiveness. On the other hand, Yoon (2002) demonstrated that a tourism destination's competitiveness is enhanced over time by strengthening its diverse elements and attractions. Concurrent with the Crouch-Ritchie model, Enright and Newton (2004) developed a more comprehensive model of tourism destination competitiveness in support of Dwyer and Kim (2003). To effectively market a tourism destination and classify it as a fully competitive destination, it is critical to incorporate natural resources and attractors into their model (e.g., floral and faunal, cultural and heritage attractions).

With these definitions, it was posited that in order to develop a tourism destination's competitiveness, it is critical for the destination to possess resources (i.e., tangible or intangible resources) and to provide services that enhance the visitor experience. Additionally, knowledge is classified as an intangible resource that contributes to the development of tourism destinations. The significance of these resources also serves as a significant draw for tourists (Nunes et al., 2018). Interestingly, there is growing interest among scholars in applying the concept of destination competitiveness and conducting case studies of various tourist destinations (e.g., Andrades and Dimanche, 2019; Fernández et al., 2020). The current study examines the sub-dimensions of tourism destination competitiveness, specifically sustainable management, destination marketing efforts, and rural tourism destinations' comparative and competitive advantage. 
Sustainable management has been identified as a critical component of destination competitiveness in previous research (Enright and Newton, 2005; Rodrguez-Daz and PulidoFernández, 2020). In the tourism context, sustainable management refers to development that meets tourist needs while also conserving local resources and improving the quality of life of local communities (Adamov et al., 2020). A rural tourism destination can be developed sustainably or irresponsibly. Indeed, one must first grasp the concept of sustainable tourism holistically in order to implement sustainable management strategies effectively (N'Drower, 2014), as many tourism operators have failed to implement sustainable tourism due to a lack of understanding and knowledge about the concept (Font and McCabe, 2017). Shen et al. (2020) suggested that it is necessary to examine tourists' support for sustainable tourism management practises. As the review indicates that sustainability is critical for the development of a successful tourism destination, this study included sustainable management as one of the sub-dimensions of tourism destination competitiveness.

Substantial evidence suggests that tourism destination marketing is an important and necessary tool for the development of tourism destinations in order to achieve sustainable tourism development (Giray et al., 2019; Matthias and Birgit, 2019). Destination marketing efforts are defined as a continuous process of identifying tourist needs and developing a marketing strategy to meet those needs through enhancement of the travel experience (Manhas, Manrai and Manrai, 2016) Indeed, destination marketing has been demonstrated to be a critical initiative in promoting local resources, acting as an attractor that influences tourists' destination selection decisions (Peceny et al., 2019). Thompson et al. (2014), for example, argued that destination marketing plays a role in changing tourist behaviour. Given the critical role of promotional efforts at the destination level in rural tourism destination development, this study included destination marketing efforts as a sub-dimension of rural tourism destination competitiveness.

Interestingly, the concepts of competitive advantage and comparative advantage are frequently applied to the service sector, specifically the tourism sector (Fernández et al., 2020). Comparative advantage is defined in the tourism context as the availability of legacies or natural and cultural resources at a tourism destination (Bobirca and Cristureanu, 2008), whereas competitive advantage is associated with the ability to effectively utilise these resources to enhance the destination's long-term competitiveness (Gupta, 2009). Additionally, previous studies have asserted that a competitive advantage can be gained through the possession of man-made resources such as tourism infrastructure and tourist facilities (Erislan, 2016). Due to the intense competition in the global tourism market, particularly post-pandemic, tourism destinations are constantly looking for new ways to improve their local attractions and level of attractiveness in order to attract tourists' attention (Guo et al., 2020). Both comparative and competitive advantages should be considered when evaluating a destination's competitiveness. Comparative and competitive advantages were included as sub-dimensions of tourism destination competitiveness in the current research study. In summary, while previous research has investigated determinants, environmental factors, the tourism destination industry's evaluation model, as well as qualitative and quantitative variables affecting tourism destination competitiveness, there is a scarcity of research on the impact of knowledge sharing as a measure in a single framework at rural tourism destinations. 


\section{Knowledge Sharing}

Within the tourism industry, it is becoming increasingly difficult for an organisation or a tourism destination to succeed and maintain a competitive edge in an uncertain and competitive environment (Mustafa et al., 2020). Nonetheless, knowledge has been identified as a critical resource for tourism and hospitality organisations seeking to remain competitive in today's turbulent marketplace (Kacperska and Lukasiewicz, 2020). As Davenport and Prusak (1998) define knowledge, it is a composite of experience, values, and contextual information that is fundamentally a human product (Puccinelli, 1998). Further, knowledge is classified into two broad categories: explicit knowledge and tacit knowledge. Historically, researchers (e.g., Ali and Ahmad, 2006) defined explicit knowledge as knowledge that can be formally and routinely documented and stored, whereas tacit knowledge is defined as undocumented knowledge or knowledge that is deeply rooted in action and gained through experience (Jain, Manjit and Gurvinder, 2007). Knowledge has been identified as a critical component of hospitality and tourism organisations' survival in today's competitive environment (Razmerita et al., 2016). Additionally, knowledge is viewed as a valuable resource for organisations or tourism-related business entities seeking a competitive edge (Swanson et al., 2020).

In this regard, the critical role of knowledge in determining the success or failure of a tourism organisation or destination has been demonstrated, and thus knowledge sharing has emerged as a strategy for firms seeking a competitive edge. Previously conducted research has identified knowledge sharing as a critical factor in determining the tourism and hospitality industry's competency and success (Yeh et al., 2011; Yiu and Law, 2012). According to Fatt and Khin (2010), knowledge sharing is an activity that entails the exchange of knowledge (e.g., information, skills, or expertise) between individuals, friends, communities, or organisations (Okyere-Kwakye and Nor, 2011; Charband and Navimipour, 2016). In the context of rural tourism, it is believed that the process of knowledge sharing could potentially result in the creation of new knowledge, as tourists sharing their tourism experiences and knowledge with the community could result in the creation of new knowledge for tourism management and development.

Furthermore, prior research has established that knowledge sharing is a necessary condition for encouraging innovation and innovativeness in the tourism and hospitality industries (Jensen, 2003; Hoarau and Kline, 2014), which results in the enhancement of competitive advantage (Scott and Laws, 2006). According to a recent study conducted by Luis et al. (2018), in order to address the challenge of long-term tourism competitiveness, a tourism destination must create an innovative ecosystem that fosters knowledge sharing among tourists and other stakeholders. Based on the numerous studies conducted, it is concluded that knowledge sharing among stakeholders tends to improve tourism development performance, including at the destination level. Additionally, Baggio and Cooper (2010) stated that the power of knowledge ownership has shifted from knowledge management to knowledge sharing, as it is reasonable to believe that knowledge sharing contributes to the creation of communities' knowledge at the destination level. Munar and Jacobsen (2014) found that tourists are accustomed to sharing their knowledge and experiences via tourism social media.

There is, however, a lack of research that establishes knowledge sharing as an independent variable and investigates its relationship to the competitiveness of rural tourism 
destinations. This research was among the first who examine the importance of knowledge sharing in the development of rural tourism destination competitiveness. Thus, this study used knowledge sharing as a predictor and incorporated it into the proposed study framework.

\section{Hypotheses Development Knowledge Sharing on Rural Tourism Destination Competitiveness}

In today's knowledge-based economy, innovativeness has been identified as a critical component of tourism businesses or destinations remaining competitive through knowledge sharing (Odunga et al., 2020). Within the tourism industry, it is becoming increasingly clear that knowledge sharing is critical for responding to change (Molose and Ezeuduji, 2015) and for tourism businesses to gain a competitive edge in today's competitive marketplace (Rao et al., 2018). Indeed, within the field of knowledge management research, a few studies have demonstrated that knowledge sharing is viewed as a critical step toward ensuring the sustainable management of competitive advantage (Islam et al., 2015). In a nutshell, knowledge sharing is the exchange of knowledge between individuals in order to generate new knowledge for innovation (Baggio and Cooper, 2008; Charband and Navimipour, 2016).

Tourists' knowledge sharing would benefit the tourism destination because it would contribute significantly to innovation for improved service quality (Jiţu et al., 2016) and sustainable management of the tourism destination. However, several studies have suggested that destinations frequently fail to implement sustainable tourism practises due to a lack of understanding and knowledge about sustainable management (N'Drower, 2014). As a result, it is critical to assess tourist support for sustainable tourism development. Thus, it is argued that tourists' willingness to share information (Money and Turner, 2004), experiences, and knowledge gained from other tourism destinations will eventually contribute to the creation of community knowledge at the destination level (Baggio and Cooper, 2010), thereby increasing the destination's efficiency of sustainable management. Additionally, it is critical to remember that the tourist is an individual who travels and visits a variety of other tourism destinations with a variety of different cultures (Buhalis, 2000). Tourists' willingness to share their experiences or knowledge gained from other tourism destinations regarding tourism destination marketing efforts would benefit tourism destination marketing efforts.

On the other hand, Liao (2003) emphasised the importance of knowledge for rural areas, stating that the availability of knowledge on preserving heritage resources, developing core competencies, and problem-solving gives destinations a competitive edge (Shaw and Williams, 2009). Tourists, it is believed, play a critical role in knowledge sharing with local community members because they are more knowledgeable and experienced when it comes to transportation, booking, and staying at various tourism destinations (Kozak, 1999). According to previous research (e.g., Kamasak and Bulutlar, 2010; Ghobadi and D'Ambra, 2011), innovation is critical for the development of competitive advantage; however, without knowledge sharing, the key to innovative tourism destination development cannot be identified completely (Mansour and Mahin, 2014). Thus, it is proposed that tourists sharing knowledge with members of the local community results in improved development or provision of tourism infrastructure and tends to improve the relationship between rural tourism destination competitiveness, specifically comparative and competitive advantage. 
Thus, it is believed that when tourists share their knowledge about tourism with members of the local community, this will help to strengthen the development of tourism destinations' competitiveness, including sustainable management, destination marketing efforts, and the comparative and competitive advantage of rural tourism destinations. Following the discussion of existing research above, the following hypotheses were developed:

H1 : Knowledge sharing is positively related to sustainable management of rural tourism destination.

$\mathrm{H} 2$ : Knowledge sharing is positively related to destination marketing efforts of rural tourism destination.

H3 : Knowledge sharing is positively related to comparative and competitive advantage of rural tourism destination.

The following research framework was proposed (see Figure 1) based on this discussion of existing research:

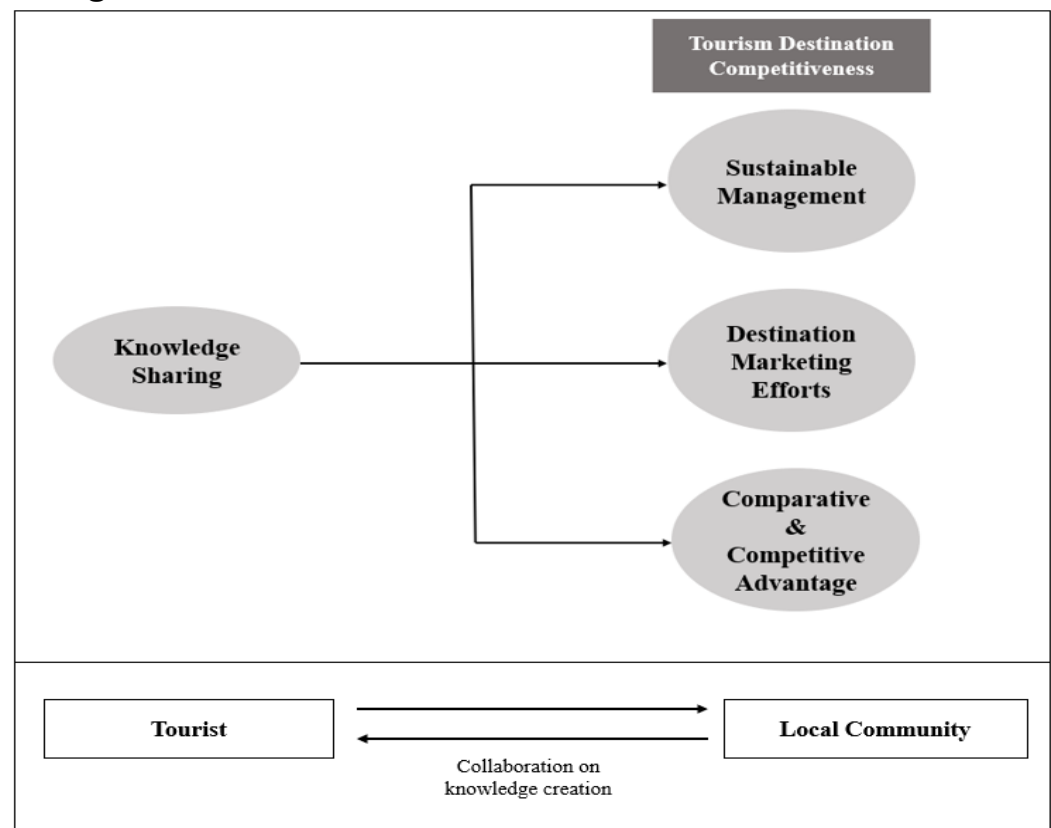

Figure 1: Conceptual model

\section{Methodology}

For data collection, a quantitative approach was used, which included the distribution of questionnaires. This study used a non-probability sampling technique, more precisely a purposive sampling technique, to select respondents aged 18 years and older, regardless of whether they were domestic or international tourists visiting the five rural tourism destinations in Sarawak. One of the reasons this study focuses on rural tourism destinations in Sarawak is that due to the region's unique combination of natural, cultural, and adventure tourism, rural tourism has developed into the region's most interesting destination for tourists. Additionally, it is well-known for rural tourism activities. The Annah Rais Bidayuh Longhouse, Kampung Po Ai Melugu, Rumah Panjang Bawang Assan, Bario Kelabit Highlands, and Ba'kelalan Homestay were used as study locations. In total, 30 items were adapted from previous research (Azzopardi and Nash, 2016; Dwyer and Kim, 2003; Liao et al., 2004; Yoon, 2002) and adapted to the Malaysian context. On a seven-point Likert scale, respondents were 
asked to rate their level of agreement with the statements (ranging from 1 for strongly disagree to 7 for strongly agree).

The minimum sample size was calculated using the G*Power (version 3.1.9.2) software. Using an a priori power analysis with a medium effect size, a significant level of 0.05 , and a power of 0.95 , the recommended minimum sample size for evaluating the research model developed is 119. A total of 315 of the 380 questionnaires were returned, indicating a response rate of 82.9 percent. Because it exceeds the suggested percentage of $70 \%$, the response rate of 82.9 percent indicates that there was no response error (Nulty, 2008). A series of preliminary analyses using Statistical Package for Social Science 23.0 were conducted prior to measurement and structural analysis to eliminate the issue of missing values and straight lining. During the process, a total of 9 sets of questionnaires were discarded, leaving 306 sets to test the measurement model's fitness and hypotheses testing. The Partial Least Square - Structural Equation Modeling (PLS-SEM) estimation procedure was performed using the WarpPLS (version 7.0) software to examine the research model developed (see Figure 1).

\section{Findings}

\section{Assessment of the Measurement Model}

The measurement scales' reliability, convergent validity, and discriminant validity were all tested using a confirmatory factor analysis (CFA). According to the results (see Table 1 , final iteration), all of the items' loadings are above 0.50 (Bagozzi et al., 1991), and all of the constructs' composite reliability (CR) and average variance extracted (AVE) are both above 0.70 (Chin, 2010) and 0.50 (Fornell and Larcker, 1981). Internal consistency was achieved as a result. For the discriminant validity shown in Table 2 , the value of AVE was square rooted and tested against the construct's inter-correlation with other constructs in the research model, with all values noted as greater than each of the constructs' correlation (Chin, 2010). As a result, the measurement model was satisfactory in terms of reliability, convergent validity, and discriminant validity. 
Table 1: Results of measurement model

\begin{tabular}{|c|c|c|c|c|c|c|c|}
\hline $\begin{array}{l}\text { Model } \\
\text { Construct }\end{array}$ & $\begin{array}{l}\text { Measuremen } \\
\text { t Item(s) }\end{array}$ & Loading & $\mathrm{CR}^{\mathrm{a}}$ & AVE $^{b}$ & Loading & $\mathrm{CR}^{\mathrm{a}}$ & AVE $^{b}$ \\
\hline & & \multicolumn{3}{|c|}{ First iteration } & \multicolumn{3}{|c|}{ Final iteration } \\
\hline $\begin{array}{l}\text { Knowledge } \\
\text { Sharing } \\
\text { (KS) }\end{array}$ & $\begin{array}{l}\text { KnowSha_01 } \\
\text { KnowSha_02 } \\
\text { KnowSha_03 } \\
\text { KnowSha_04 } \\
\text { KnowSha_05 }\end{array}$ & $\begin{array}{l}0.799 \\
0.807 \\
0.815 \\
0.824 \\
0.833\end{array}$ & 0.909 & 0.666 & $\begin{array}{l}0.799 \\
0.807 \\
0.815 \\
0.824 \\
0.833\end{array}$ & 0.909 & 0.666 \\
\hline $\begin{array}{l}\text { Sustainable } \\
\text { Manageme } \\
\text { nt (SM) }\end{array}$ & $\begin{array}{l}\text { SustMan_01 } \\
\text { SustMan_02 } \\
\text { SustMan_03 } \\
\text { SustMan_04 } \\
\text { SustMan_05 } \\
\text { SustMan_06 }\end{array}$ & $\begin{array}{l}0.783 \\
0.809 \\
0.825 \\
0.594 \\
0.531 \\
0.609\end{array}$ & 0.850 & 0.492 & $\begin{array}{c}0.802 \\
0.857 \\
0.876 \\
0.622 \\
\text { Omitted } \\
0.501\end{array}$ & 0.855 & 0.557 \\
\hline $\begin{array}{l}\text { Destination } \\
\text { Marketing } \\
\text { Efforts } \\
\text { (DME) }\end{array}$ & $\begin{array}{l}\text { DME_01 } \\
\text { DME_02 } \\
\text { DME_03 } \\
\text { DME_04 } \\
\text { DME_05 }\end{array}$ & $\begin{array}{l}0.593 \\
0.494 \\
0.755 \\
0.740 \\
0.800 \\
\end{array}$ & 0.812 & 0.471 & $\begin{array}{c}0.565 \\
\text { Omitted } \\
0.734 \\
0.792 \\
0.846 \\
\end{array}$ & 0.827 & 0.550 \\
\hline $\begin{array}{l}\text { Comparativ } \\
\text { e \& } \\
\text { Competitive } \\
\text { Advantage } \\
\text { (C\&Cadv) }\end{array}$ & $\begin{array}{l}\text { C_CAdv_01 } \\
\text { C_CAdv_02 } \\
\text { C_CAdv_03 } \\
\text { C_CAdv_04 } \\
\text { C_CAdv_05 } \\
\text { C_CAdv_06 } \\
\text { C_CAdv_07 } \\
\text { C_CAdv_08 } \\
\text { C_CAdv_09 } \\
\text { C_CAdv_10 } \\
\text { C_CAdv_11 } \\
\text { C_CAdv_12 } \\
\text { C_CAdv_13 } \\
\text { C_CAdv_14 }\end{array}$ & $\begin{array}{l}0.650 \\
0.296 \\
0.771 \\
0.759 \\
0.791 \\
0.714 \\
0.718 \\
0.734 \\
0.541 \\
0.597 \\
0.149 \\
0.084 \\
0.118 \\
0.122\end{array}$ & 0.840 & 0.327 & $\begin{array}{c}0.642 \\
\text { Omitted } \\
0.758 \\
0.758 \\
0.806 \\
0.719 \\
0.739 \\
0.745 \\
0.554 \\
0.593 \\
\text { Omitted } \\
\text { Omitted } \\
\text { Omitted } \\
\text { Omitted }\end{array}$ & 0.898 & 0.500 \\
\hline
\end{tabular}

Note: Items SustMan_05, DME_02, C_Cadv_02, C_Cadv_11, C_Cadv_12, C_Cadv_13 and C_Cadv_14 were deleted due to low loadings.

${ }^{a}$ Composite Reliability (CR) $\quad{ }^{b}$ Average Variance Extracted (AVE)

Source: Authors

Table 2: Discriminant validity of constructs

1. Knowledge Sharing

2. Sustainable Management

3. Destination Marketing Efforts

4. Comparative \& Competitive Advantage
1

0.816

0.156

0.085

0.058

2

(2)

3

\begin{tabular}{c|c|}
\hline 3 & 4 \\
& \\
0.742 & \\
0.568 & 0.706 \\
\hline
\end{tabular}

Note: Diagonals represent the square root of the average variance extracted (AVE) while the other entries represent the correlations.

Source: Author 


\section{Assessment of the Structural Model}

The results of hypotheses testing are presented in Table 3 and Figure 2. For one-tailed hypotheses testing, the $t$ value should be greater than $1.645(p<0.05)$ or $2.33(p<0.01)$. Surprisingly, the statistical findings showed that all three direct relationship hypotheses tested were supported. Knowledge sharing was discovered to have a positive significant relationship with rural tourism destination competitiveness, including sustainable management, destination marketing efforts, and comparative and competitive advantage from the perspective of tourists. As a result, the statistical findings indicated that $\mathrm{H} 1, \mathrm{H} 2$, and H3 were supported. To explain the model's predictive relevance, the Q2 value was obtained with the values of 0.116 (sustainable management), 0.048 (destination marketing efforts), and 0.025 (comparative and competitive advantage), which is consistent with Hair et al., (2017)'s suggestion that a Q2 value greater than zero is relevant.

Table 3: Path coefficients and hypothesis testing

\begin{tabular}{|c|c|c|c|c|c|}
\hline $\begin{array}{l}\text { Hypothesi } \\
\text { s }\end{array}$ & Relationship & $\begin{array}{l}\text { Standard } \\
\text { Beta }\end{array}$ & P-value & t-value & Decision \\
\hline $\mathrm{H} 1$ & $\begin{array}{l}\text { Knowledge Sharing } \rightarrow \\
\text { Sustainable Management }\end{array}$ & 0.348 & $<0.001$ & $\begin{array}{l}7.243 * \\
*\end{array}$ & Supported \\
\hline $\mathrm{H} 2$ & $\begin{array}{l}\text { Knowledge Sharing } \rightarrow \\
\text { Destination Marketing } \\
\text { Efforts }\end{array}$ & 0.227 & $<0.001$ & $\begin{array}{l}4.635^{*} \\
*\end{array}$ & Supported \\
\hline H3 & $\begin{array}{l}\text { Knowledge Sharing } \rightarrow \\
\text { Comparative \& Competitive } \\
\text { Advantage }\end{array}$ & 0.154 & $<0.001$ & $\begin{array}{l}3.115^{*} \\
*\end{array}$ & Supported \\
\hline
\end{tabular}

Note: $\mathrm{p}<0.01^{* *}=\mathrm{t}>2.33 ; \mathrm{p}<0.05=\mathrm{t}>1.645^{*}$

Source: Authors

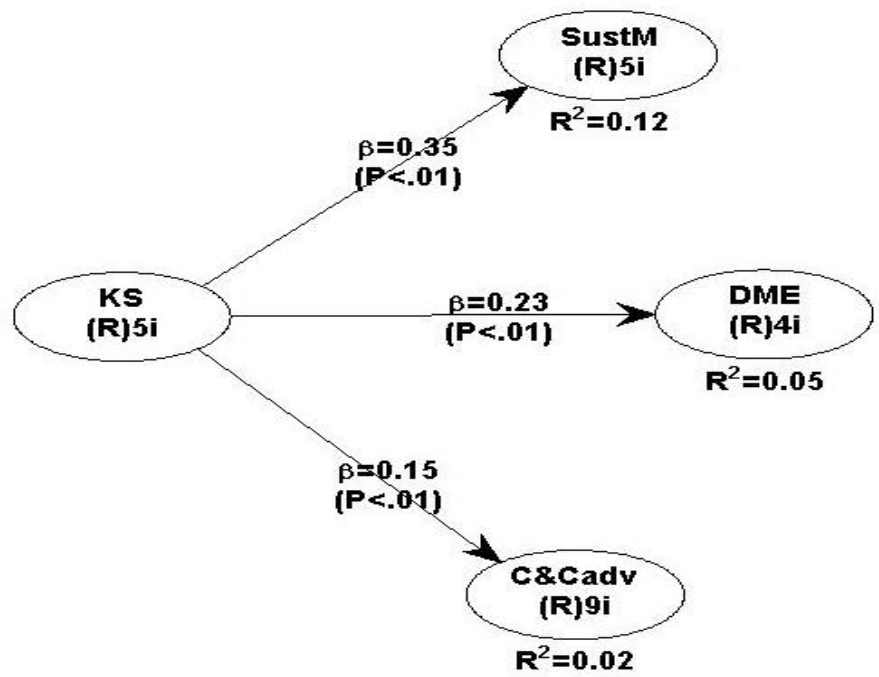

Figure 2: Research model with Path Coefficient and P-Values

\section{Discussion}

While the total number of tourists visiting rural tourism destinations in Sarawak is undoubtedly small at the moment, capturing the perspectives of these groups of tourists on the factors that most influenced their decision to visit rural tourism destinations in Sarawak could benefit other rural tourism destinations in Sarawak for the purpose of destination 
comparison. It is even more valuable in the post-pandemic period for rural tourism development. Recognizing the critical nature of innovation, particularly in the area of intangible resources in the tourism and hospitality industries, knowledge sharing is identified as a critical initiative to aid in the innovation process. The purpose of this study was to determine the significance of knowledge sharing in the development of rural tourism destination competitiveness (i.e., sustainable management, destination marketing efforts, as well as comparative and competitive advantage) in rural Sarawak.

All three direct hypotheses proposed were found to be supported. For hypothesis 1 , knowledge sharing was found to be positively associated with the sustainable management of rural tourism destinations from the perspective of tourists $(\beta=0.348 ; p=<0.001 ; t=7.243$ ). It is believed that tourists' willingness to share information, experiences, and knowledge gained from other tourism destinations can help develop local knowledge at the destination level. This knowledge is critical because it can assist the community in improving the tourism destination's hard and soft infrastructure. Finally, the knowledge gained will help to improve the efficiency of rural tourism destination management. On the other hand, the statistical results for hypothesis 2 indicate that knowledge sharing is positively associated with rural tourism destination marketing efforts $(\beta=0.227 ; p=\langle 0.001 ; t=4.635)$, indicating that the hypothesis is supported as proposed. Sharing knowledge and experience with local communities is believed to contribute to the development of destination marketing plans.

Finally, the statistical results for hypothesis $3(\beta=0.154 ; p=<0.001 ; t=3.115)$ supported the proposed hypothesis, which is that knowledge sharing has a positive and significant relationship with rural tourism destinations' comparative and competitive advantage in the eyes of tourists. Local communities want to provide the best services possible to tourists, but they need to understand precisely what tourists want in terms of attractions, infrastructure, and service quality. The statistical findings of this study affirm Paroutis and Al Saleh's (2009) finding that knowledge sharing between two tourists and communities can result in the generation of new knowledge for the development of a tourism destination's competitiveness. To summarise, in order to develop a competitive rural tourism destination, tourism stakeholders must consider the perspective of tourists, as the developed tourism destination's ultimate goal is to satisfy and fulfil tourists' needs. Thus, local governments, communities, and entrepreneurs are encouraged to engage with tourists and share knowledge in order to gain a better understanding of how to develop rural tourism destinations' competitiveness in rural areas.

\section{Conclusion, Implications and Limitations}

As with any research, this study has several limitations. To begin, this study relies heavily on samples drawn from tourists, both international and domestic, who visited the rural tourism destinations in Sarawak, Malaysia that were chosen for this study. The cultural differences between rural tourism destinations in Sarawak and rural tourism destinations in other countries may limit the generalizability of the findings. The reason for this is that various rural tourism destinations may offer tourists a variety of experiences. Second, data collection occurred at a single point in time, rather than at multiple points in time. As a result, the study's causal effect cannot be determined because data were collected at a single point in time and not from the same group of participants over a longer period of time. As a result, this study could only present conclusions and discussions about the general relationships between 
variables, as well as the moderating effect. In short, a longitudinal study should be conducted in place of the cross-sectional study to ascertain the study's causal effect.

The study concludes by demonstrating that knowledge sharing is both significant and positively correlated with rural tourism destination competitiveness in Sarawak, Malaysia. The findings have unavoidably contributed to the fundamental concept of destination competitiveness through the creation of resources for the development of rural tourism destination competitiveness and its contribution to sustainable management, destination marketing efforts, as well as the comparative and competitive advantage of rural tourism destinations that are currently lacking in rural tourism. This study makes several significant contributions to the development of theory and management practises. Theoretically, this study inevitably and successfully developed some guidelines for scholars and practitioners interested in the competitiveness of rural tourism destinations. For example, this is the first study to examine knowledge sharing and its impact on the competitiveness of rural tourism destinations in Sarawak, Malaysia. Thus, this study contributes to the literature from an Asian country's geographical perspective. Additionally, this study established the relevance of Social Exchange Theory in guiding the research framework pertaining to knowledge sharing in order to increase the competitiveness of tourism destinations from a tourist perspective.

In practise, the findings of this study provide valuable information to tourism stakeholders such as local communities, industry players, and tourism-related government departments about tourists' concerns when making decisions to visit rural tourism destinations, particularly tourists who believe that sharing knowledge could potentially help in the development of rural tourism destinations' competitiveness. For example, this study's findings confirmed that tourists are willing to share their knowledge with members of the local community, and that this process of knowledge sharing can result in the creation of new knowledge for the better development of tourism destinations and their competitiveness. As a result, tourism planners should be concerned about the importance of knowledge sharing and develop a proper and structured platform to encourage tourists to share their valuable knowledge with the rural local community, as well as develop a better idea or strategy to build or form a competitive rural tourism destination. The current study examines tourists' willingness to share knowledge with local tourism operators, and concludes that the best platform for sharing knowledge from both a "tourist" and a "community" perspective is required. Thus, future research should focus on determining which platforms are the best for knowledge sharing. One possible venue for knowledge sharing is during the cultural night. It is essentially an event that occurs toward the end of a tourist's visit, during which cultural and feedback exchanges take place between tourists and community members.

\section{References}

Adamov, T., Ciolac, R., lancu, T., Brad, I., Pet, E., Popescu, G., and Smuleac, L. (2020), "Sustainability of Agritourism Activity. Initiatives and Challenges in Romanian Mountain Rural Regions", Sustainability, Vol. 12, pp. 1-23. DOI: https://doi.org/10.3390/su12062502

Albino, S. J., Rodrigues, P., Mendes, J., and Periera, L. N. (2010), "A tourism research agenda for Portugal", The International Journal of Tourism Research, Vol. 12 No. 1, pp. 90-101. DOI: https://doi.org/10.1002/jtr.740 
Ali, H. M., and Ahmad, N. H. (2006), "Knowledge management in Malaysian banks: A new paradigm", Journal of Knowledge Management Practice, Vol. 7 No. 3, pp. 1-13.

Ali, L., and Avdic, A. (2015), "A knowledge management framework for sustainable rural development: The case of Gilgit-Baltistan, Pakistan", The Electronic Journal of Knowledge Management, Vol. 13 No. 2, pp. 103-165.

Andrades, L., and Dimanche, F. (2019), "Destination competitiveness in Russia: tourism professional's skills and competences", International Journal of Contemporary Hospitality Management, Vol. 31 No. 2, pp. 910-930. DOI: https://doi.org/10.1108/IJCHM-11-2017-0769

Ap, J. (1992), "Residents' perceptions on tourism impacts", Annals of Tourism Research, Vol. 19 No. 3, pp. 665-690. DOI: https://doi.org/10.1016/0160-7383(92)90060-3

Azzopardi, E. and Nash, R. (2016), "A framework for island destination competitiveness - perspectives from the island of Malta", Current Issues in Tourism, Vol. 19 No. 3, pp. 253-281. DOI: https://doi.org/10.1080/13683500.2015.1025723

Baggio, R., and Cooper, C. (2008), "Knowledge management and transfer in tourism: An Italian case", Proceedings in IASK - Advances in Tourism Research, May 26-28, Aveiro, Portugal.

Baggio, R, and Cooper, C. (2010), "Knowledge transfer in a tourism destination: the effects of a network structure", The Service Industries Journal, Vol. 30 No. 10, pp. 1757-1771. DOI: https://doi.org/10.1080/02642060903580649

Bagozzi, R. R., Yi, Y., and Philipps, L. W. (1991), "Assessing construct validity in organizational research", Administrative Science Quarterly, Vol. 36 No. 3, pp. 421-458. DOI: https://doi.org/10.2307/2393203

Bobirca, A., and Cristureanu, C. (2008), "Analyzing Romania's competitiveness as a tourism destination", Advances in Hospitality Leisure, Vol. 4, pp. 75-99. DOI: https://doi.org/10.1016/S1745-3542(08)00004-0

Bock, G. W., Zmud, R. W., Kim, Y. G., and Lee, J. N. (2005), "Behavioral intention formation in knowledge sharing: Examining the roles of extrinsic motivators, social-psychological factors, and organizational climate", MIS Quarterly, Vol. 29 No. 1, pp. 87-111. DOI: https://doi.org/10.2307/25148669

Buhalis, D. (2000), "Marketing the competitive destination of the future", Tourism Management, Vol. 21 No. 1, pp. 97-116. DOI: https://doi.org/10.1016/S02615177(99)00095-3

Campón-Cerro, A. M., Hernández-Mogollón, J. M., and Alves, H. (2017), "Sustainable improvement of competitiveness in rural tourism destinations: The quest for tourist loyalty in Spain", Journal of Destination Marketing and Management, Vol. 6 No. 3, pp. 252-266. DOI: https://doi.org/10.1016/j.jdmm.2016.04.005

Charband, Y., and Navimipour, N. J. (2016), "Online knowledge sharing mechanisms: A systematic review of the state of the art literature and recommendations for future research", Information Systems Frontiers, Vol. 18, pp. 1131-1151. DOI: https://doi.org/10.1007/s10796-016-9628-z

Cheuk, S., Lo, M. C., and Atang, A. (2015), "Rural tourism destination performance in East Malaysia: Influencing factors from the communities' perspective", Journal of Sustainable Development, Vol. 8 No. 3, pp. 124-138. DOI: https://doi.org/10.5539/jsd.v8n3p124

Chin, W. W. (2010), "How to write up and report PLS analyses", In V. Esposito Vinzi, W. W. Chin, J. Henseler, \& H. Wang (Eds.), Handbook of partial least squares: Concepts, 
methods and application. New York: Springer, pp. 645-689. DOI: https://doi.org/10.1007/978-3-540-32827-8_29

Ching, J. L., Lo, M. C., Suaidi, M. K., Mohamad, A. A., and Chin, C. H. (2019), "Tourists' perspective on ecotourism destination competitiveness: The role of tangible components", International Journal of Academic Research in Business and Social Science, Vol. 9 No. 10, pp. 335-357. DOI: http://dx.doi.org/10.6007/IJARBSS/v9i11/6552

Cook, K. (2000), "Charting futures for sociology: Structure and actions", Contemporary Sociology, Vol. 29 No. 5, pp. 685-692. DOI: https://doi.org/10.2307/2655233

Crouch, G. I., and Ritchie, J. R. B. (1999), "Tourism, Competitiveness, and Societal Prosperity", Journal of Business Research, Vol. 44 No. 3, pp. 137-152. DOI: https://doi.org/10.1016/S0148-2963(97)00196-3

Davenport, T. H., and Prusak, L. (1998), "Working knowledge: How organizations manage what they know", Boston: Harvard Business School Press.

Demirović, D., Petrović, M. D., Monteiro, L. C. N., and Stjepanović, S. (2016), “An examination of competitiveness of rural destinations from the supply side perspective", Journal of the Geographical Institute Jovan Cvijic, Vol. 66 No. 3, pp. 387-400. DOI: https://doi.org/10.2298/IJGI1603387D

Dwyer, L., and Kim, C. (2003), "Destination competitiveness: Determinants and indicators", Current Issues in Tourism, Vol. 6 No. 5, pp. 369-414. DOI: https://doi.org/10.1080/13683500308667962

Enright, M., and Newton, J. (2005), "Determinants of tourism destination competitiveness in Asia Pacific: Comprehensiveness and Universality", Journal of Travel Research, Vol. 43 No. 4, pp. 339-350. DOI: https://doi.org/10.1177/0047287505274647

Erislan. (2016), "Tourist attraction and the uniqueness of resources on tourist destination in West Java, Indonesia", Review of Integrative Business and Economics Research, Vol. 5 No. 1, pp. 251-266. DOI: https://ssrn.com/abstract=2864086

Fatt, C. K., and Khin, E. W. S. (2010), "The social-technical view of knowledge management in services industries", Journal of Social Sciences, Vol. 6 No. 2, pp. 256-264. DOI: https://doi.org/10.3844/jssp.2010.256.264

Fernández, J. A. S., Azevedo, P. S., Martín, J. M. M., and Martín, J. A. R. (2020), “Determinants of tourism destination competitiveness in the countries most visited by international tourists: Proposal of a synthetic index", Tourism Management Perspectives, Vol. 33, pp. 1-13. DOI: https://doi.org/10.1016/j.tmp.2019.100582

Font, X.. and McCabe, S. (2017), "Sustainability and marketing in tourism: its contexts, paradoxes, approaches, challenges and potential", Journal of Sustainable Tourism, Vol. 25 No. 7, pp. 869-883. DOI: https://doi.org/10.1080/09669582.2017.1301721

Fornell, C. (1992), "A national customer satisfaction barometer: The Swedish experience", Journal of Marketing, Vol. 56 No. 1, pp. 6-21. DOI: https://doi.org/10.2307/1252129

Fornell, C., and Larcker, D. F. (1981), "Evaluating structural equation models with unobservable variables and measurement error", Journal of Marketing Research, Vol. 18 No. 1, pp. 39-50. DOI: https://doi.org/10.1177/002224378101800104

Fouad, F., Tourabi, A., and Lakhnati, G. (2017), "The impact of tangible and intangible innovation activities on the new product objectives in three phases of the innovation process: Case of the fish industry - Morocco", Technology and Investment, Vol. 8, pp. 11-32. DOI: https://doi.org/10.4236/ti.2017.81002 
Ghobadi, S., and D'Ambra, J. (2011), “Coopetitive knowledge sharing: An analytical review of literature", Electronic Journal of Knowledge Management, Vol. 9 No. 4, pp. 307-317.

Giray, F. H., Kadakoğlu, B., Çetin, F., and Bamoi, A. G. A. (2019), "Rural tourism marketing: Lavender tourism in Turkey", Ciência Rural, Vol. 49 No. 2, pp. 1-15. DOI: https://doi.org/10.1590/0103-8478cr20180651

Guenther, T. W., and Heinicke, A. (2019), "Relationships among types of use, levels of sophistication, and organizational outcomes of performance measurement systems: The crucial role of design choices", Management Accounting Research, Vol. 42, pp. 125. DOI: https://doi.org/10.1016/j.mar.2018.07.002

Guo, S., Jiang, Y., and Long, W. (2020), "Urban tourism competitiveness evaluation system and its application: Comparison and analysis of regression and classification methods", Procedia in Computer Science, Vol. 162, pp. 429-437. DOI: https://doi.org/10.1016/j.procs.2019.12.007

Gupta, S. D. (2009), "Comparative advantage and competitive advantage: An economics perspective and a synthesis", Athens Journal of Business and Economics, Vol. 1 No. 1, pp. 9-22. DOI: https://doi.org/10.30958/ajbe.1-1-1

Hair, J., Hult, G. T. M., Ringle, C. M., and Sarstedt, M. (2017), "A primer on partial least squares structural equation modeling", 2nd ed. Thousand Oaks, CA: Sage.

Hansen, E. G., and Schaltegger, S. (2016), "The sustainability balanced scorecard: A systematic review of architectures", Journal of Business Ethics, Vol. 133, pp. 193-221. DOI: https://doi.org/10.1007/s10551-014-2340-3

Hoarau, H., and Kline, C. (2014), "Science and industry: Sharing knowledge for innovation", Annals of Tourism Research, Vol.46, pp. 44-61. DOI: https://doi.org/10.1016/j.annals.2014.01.005

Islam, M. Z., Jasimuddin, S. M., and Hasan, I. (2015), “Organizational culture, structure, technology infrastructure and knowledge sharing: Empirical evidence from MNCs based in Malaysia", VINE, Vol. 45 No. 1, pp. 67-88. DOI: https://doi.org/10.1108/VINE05-2014-0037

Jaafar, M., Bakri, N.M. and Rasoolimanesh, S.M. (2015), "Local community and tourism development: A study of rural mountainous destinations", Modern Applied Science, Vol. 9 No. 8, pp. 399-408. DOI: https://doi.org/10.5539/mas.v9n8p399

Jain, K. K., Manjit, S. S., and Gurvinder, K. S. (2007), "Knowledge sharing among academic staff: A case study of Business Schools in Klang Valley, Malaysia', Journal of the Advancement of Science and Arts, Vol. 2, pp. 23-29.

Jensen, S. (2003), "Knowledge creation and transfer in the tourism industry. Results from a study in the county of storstrom, Denmark", Paper presented at the DRUID Summer Conference on Creating, Sharing, and Transferring Knowledge. The Role of Geography, Institutions, and Organizations, 12-14 June, Copenhagen.

Joyner, L., Lackey, Q., and Bricker, K. (2018), "Ecotourism Outlook 2018.", In 2018 Outlook Marketing Forum (p. 1). Las Vegas: Travel and Tourism Research Association. Retrieved from https://tra.com/wp-content/uploads/2018/11/Ecotourism-Outlook2018.pdf

Kacperska, E., and Łukasiewicz, K. (2020), "The Importance of trust in knowledge sharing and the efficiency of doing business on the example of tourism", Information, Vol. 11 No. 311, pp. 1-18. DOI: https://doi.org/10.3390/info11060311 
Kamasak, R., and Bulutlar, F. (2010), "The influence of knowledge sharing on innovation", European Business Review, Vol. 22 No. 3, pp. 306-317. DOI: https://doi.org/10.1108/09555341011040994

Kim, T. T., and Lee, G. (2013), "Hospitality employee knowledge-sharing behaviors in the relationship between goal orientations and service innovative behaviour", International Journal of Hospitality Management, Vol. 34, pp. 324-337. DOI: https://doi.org/10.1016/j.ijhm.2013.04.009

Kozak, M. (1999), "Destination competitiveness measurement: Analysis of effective factors and indicators", The 39th. European Regional Science Association Conference (No. 289). Vienna: European Regional Science Association. DOI: http://hdl.handle.net/10419/114351

Lee, T. H. (2013), "Influence analysis of community resident support for sustainable tourism development", Tourism Management, Vol. 34, pp. 37-46. DOI: https://doi.org/10.1016/j.tourman.2012.03.007

Liao, S. (2003), "Knowledge management technologies and applications - Literature review from 1995 to 2002", Expert Systems with Applications, Vol. 25 No. 2, pp. 155-165. DOI: https://doi.org/10.1016/S0957-4174(03)00043-5

Liao, S-H., Chang, J. C., Cheng, S-C., and Kuo, C-M. (2004), "Employee relationship and knowledge sharing: A case study of a Taiwanese finance and securities firm", Knowledge Management Research \& Practice, Vol. 2 No. 1, pp. 24-34. DOI: https://doi.org/10.1057/palgrave.kmrp.8500016

Luis, M. I., Ana, R. R., María, J. S. D. (2018), "The challenge of long-term tourism competitiveness in the age of innovation: Spain as a case study", Investigaiones Regionales - Journal of Regional Research, Vol. 42, pp. 13-34.

Manhas, P. S., Manrai, L. A., and Manrai, A. K. (2016), "Role of tourist destination development in building its brand image: A conceptual model", Journal of Economics, Finance and Administrative Science, Vol. 21 No. 40, pp. 25-29. DOI: https://doi.org/10.1016/j.jefas.2016.01.001

Matthias, F., and Birgit, P. (2019), "Destination image analysis - A cross-cultural segmentation approach", In proceedings TTRA, Glasgow.

Molose, T., and Ezeuduji, I.O. (2015), "Knowledge sharing, team culture, and service innovation in the hospitality sector: The case of South Africa", African Journal of Hospitality, Tourism and Leisure, Vol. 4 No. 1, pp. 1-16.

Money, W., and Turner, A. (2004), "Application of the technology acceptance model to a knowledge management system", Proceedings of the 37th Hawaiian Conference on Systems Science.

Munar, A. M., and Jacobsen, J. K. S. (2014), "Motivations for sharing tourism experiences through social media", Tourism Management, Vol. 43, pp. 46-54. DOI: https://doi.org/10.1016/j.tourman.2014.01.012

Mustafa, H., Omar, B., and Mukhiar, S. N. S. (2020), "Measuring destination competitiveness: An importance-performance analysis (IPA) of six top island destinations in South East Asia", Asia Pacific Journal of Tourism Research, Vol. 25 No. 3, pp. 223-243. DOI: https://doi.org/10.1080/10941665.2019.1687534

N'Drower, F. P. (2014), "Sustainable rural tourism practices in Madang Province, Papua New Guinea", Contemporary PNG Studies: DWU Research Journal, Vol. 20, pp. 90-102.

Newall, L. E. (1992), "The Challenge of Competitiveness", Business Quarterly, Vol. 56 No. 4, pp. 94-100. 
Nickerson, J. A., and Zenger, T. R. (2004), "A knowledge-based theory of the firm - the problem-solving perspective", Organization Science, Vol. 15 No. 6, pp. 617-632. DOI: https://doi.org/10.1287/orsc.1040.0093

Nulty, D.D. (2008), "The adequacy of response rates to online and paper surveys: what can be done?", Journal of Assessment and Evaluation in Higher Education, Vol. 33 No. 3, pp. 301-314. DOI: https://doi.org/10.1080/02602930701293231

Nunes, S., Estevão, C., and Filipe, M. N. (2018), "Determinant factors of competitiveness in the hotel sector: The case of Portugal", Competitiveness Review: An International Business Journal, Vol. 28 No. 2, pp. 122-135. DOI: https://doi.org/10.1108/cr-07-20160043

Odunga, E. W., Kieti, D., and Too, J. K. (2020), "Influence of knowledge sharing by tourism stakeholders on a destination's competitiveness, Baringo County - Kenya", International Journal of Economics, Commerce and Management, Vol. VIII No. 4, pp. 26-55.

Okyere-Kwakye, E., and Nor, K. M. (2011), "Individual factors and knowledge sharing", American Journal of Economics and Business Administration, Vol. 3 No. 1, pp. 66-72. DOI: https://doi.org/10.3844/ajebasp.2011.66.72

Paroutis, S. and Al Saleh, A. (2009), "Determinants of knowledge sharing using web 2.0 technologies", Journal of Knowledge Management, Vol. 13 No. 4, pp. 52-63.

Peceny, U. S., Urbančič, J., Mokorel, S., Kuralt, V., and Ilijaš, T. (2019), “Tourism 4.0: Challenges in Marketing a Paradigm Shift", Chapter in Book: Consumer Behavior and Marketing. DOI: https://doi.org/10.5772/intechopen.84762

Porter, M. (1985), "Competitive advantage: Creating and sustaining superior performance", New York: The Free Press.

Porter, M. E. (1990), "The competitive advantage of nations", New York: Free Press.

Puccinelli, B. (1998), "Strategies for sharing knowledge", Inform, Vol. 12 No. 9, pp. 40-41.

Rahmiati, F., Othman, N. A., and Tahir, M. N. H. (2020), "Examining the trip experience on competitive advantage creation in tourism", International Journal of Economics and Business Administration, Vol. VIII No. 1, pp. 15-30.

Rajaratnam, S. D., and Nair, V. (2015), “Destination quality and tourists' behavioral intentions: Rural tourist destinations in Malaysia", Worldwide Hospitality and Tourism Themes, Vol. 7 No. 5, pp. 463-472. DOI: https://doi.org/10.1108/WHATT-06-2015-0026

Rao, Y., Yang, M., and Yang, Y. (2018), "Knowledge sharing, organizational learning and service innovation in tourism", Journal of Service Science and Management, Vol. 11 No. 5, pp. 510-526. DOI: https://doi.org/ 10.4236/jssm.2018.115035

Razmerita, L., Kirchner, K., and Nielsen, P. (2016), "What factors influence knowledge sharing in organizations? A social dilemma perspective of social media communication", Journal of Knowledge Management, Vol. 20 No. 6, pp. 1225-1246. DOI: https://doi.org/10.1108/JKM-03-2016-0112

Rodríguez-Díaz, B., and Pulido-Fernández, J. I. (2020), "Analysis of the worth of the weights in a new Travel and Tourism Competitiveness Index", Journal of Travel Research, Vol. 60 No. 2, pp. 1-14. DOI: https://doi.org/10.1177/0047287519899982

Sapari, M. S., Shuib, A., Ramachandran, S., and Kunasekaran, P. (2019), "Contributions of Tourism Micro and Small Entrepreneurs to Local Community Livelihood", SSRG International Journal of Economics and Management Studies, Vol. 6 No. 8, pp. 182189. 
Scott, D., Hall, C. M., and Gössling, S. (2019), "Global tourism vulnerability to climate change", Annals of Tourism Research, Vol. 77, pp. 49-61. DOI: https://doi.org/10.1016/j.annals.2019.05.007

Scott, N., and Laws, E. (2006), "Knowledge sharing in tourism and hospitality", In: Scott, N. \& Laws, E. (eds.), Knowledge Sharing and Quality Assurance in Hospitality and Tourism. New York: The Haworth Hospitality Press, pp. 1-12. DOI: https://doi.org/10.4324/9780203051818

Shaw, G., and Williams, A. M. (2009), "Knowledge transfer and management in tourism organisations: An emerging research agenda", Tourism Management, Vol. 30 No. 3, pp. 325-335. DOI: https://doi.org/10.1016/j.tourman.2008.02.023

Shen, S., Sotiriadis, M., and Zhou, Q. (2020), "Could Smart Tourists Be Sustainable and Responsible as Well? The Contribution of Social Networking Sites to Improving Their Sustainable and Responsible Behavior", Sustainability, Vol. 12, pp. 1470-1490. DOI: https://doi.org/10.3390/su12041470

Silva, R., and Oliveira, C. (2020), "The influence of innovation in tangible and intangible resource allocation: A qualitative multi case study", Sustainability, Vol. 12, pp. 49895010. DOI: https://doi.org/10.3390/su12124989

Swanson, E., Kim, S., Lee, S. M., Yang, J. J., and Lee, Y. K. (2020), "The effect of leader competencies on knowledge sharing and job performance: Social capital theory", Journal of Hospitality and Tourism Management, Vol. 42, pp. 88-96. DOI: https://doi.org/10.1016/j.jhtm.2019.11.004

Thompson, F. M., Newman, A., and Liu, M. (2014), "The moderating effect of individual level collectivist values on brand loyalty", Journal of Business Research, Vol. 67 No. 11, pp. 2437-2446. DOI: https://doi.org/10.1016/j.jbusres.2014.02.011

Tîţu, M. A., Răulea, A. S., and Jîţu, Ş. (2016), "Measuring service quality in tourism industry", Procedia - Social and Behavioral Sciences, Vol. 221, pp. 294-301. DOI: https://doi.org/10.1016/j.sbspro.2016.05.118

UNDP. (2013), "Knowledge Sharing", Retrieved from http://www.undp.org/content/undp/en/home/ourwork/knowledge_exchange/

Wang, Y., and Pfister, R. E. (2008), "Residents' attitudes toward tourism and perceived personal benefits in a rural community", Journal of Travel Research, Vol. 47 No. 1, pp. 84-93. DOI: https://doi.org/10.1177/0047287507312402

Yeh, C. M., Hu, H. N., \& Tsai, S. H. (2011), "A conceptual model of knowledge sharing and market orientation in the tourism sector", American Journal of Applied Sciences, Vol. 8 No. 4, pp. 343-347.

Yiu, M., and Law, R. (2012), "Factors influencing knowledge sharing behavior: A socialpsychological view in tourism", Service Science, Vol. 3 No. 2, pp. 11-31.

Yoon, Y. (2002), "Development of a structural model for tourism destination competitiveness from stakeholders' perspectives", Dissertation submitted to the Faculty of the Virginia Polytechnic Institute and State University in partial fulfillment of the requirement for the degree of Doctor of Philosophy in Hospitality and Tourism Management.

Zaei, M. E., and Zaei, M. E. (2014), "Knowledge management in hospitality and tourism industry: A KM research perspective", Information and Knowledge Management, Vol. 4 No. 9, pp. 114-122. 